\title{
Borrelia miyamotoi: egy újabb, humán patogén, kullancs által terjesztett, visszatérő lázat okozó baktérium
}

\author{
Szekeres Sándor ${ }^{1}$ - Lakos András dr. ${ }^{2}$ - Földvári Gábor dr. ${ }^{1}$ \\ 1Állatorvostudományi Egyetem, Parazitológiai és Állattani Tanszék, Budapest \\ ${ }^{2}$ Kullancsbetegségek Ambulanciája, Budapest
}

\begin{abstract}
A Borrelia miyamotoi-t 1995-ben fedezték fel. Ez egy, emberben visszatérő lázat (relapsing fever, febris recurrens) okozó baktérium, amelyet az Ixodes ricinus fajcsoportba tartozó kullancsok terjesztenek. Ez a kórokozó genetikailag, járványtanilag és az általa okozott kórkép tekintetében is különbözik a szintén kullancsok által terjesztett Borrelia burgdorferi sensu lato (Lyme spirochaeta) baktériumoktól. Eddig világszerte több mint 50 heveny lázas megbetegedésben szenvedő páciensbőll mutatták már ki, ezenfelül három tumoros betegben meningoencephalitist okozott ez a kórokozó. A különböző élőhelyeken található kullancsok és gazdáik fertőzöttségének mértéke, eloszlása és a fertőzés mechanizmusa nem tisztázott még. A B. miyamotoi elsősorban lázat okoz, ami miatt más, kullancsok által terjesztett fertőzésekkel is összetéveszthető. Az utóbbi évek intenzív vizsgálatai alapján nemcsak egyre több földrajzi régióból mutatják ki ezt a baktériumot kullancsokból, de folyamatosan növekszik a publikált humán esetszám is, ezért növekvő jelentőségú (emerging) kórokozóként tartják számon. Irodalmi áttekintésünkben összegezzük az eddigi ismereteinket a Borrelia miyamotoi-val kapcsolatban.
\end{abstract}

Orv Hetil. 2017; 158(29): 1124-1130.

Kulcsszavak: Borrelia miyamotoi, kullancs, visszatérő láz, kullancs által terjesztett fertőzések

\section{Borrelia miyamotoi: a recently identified human pathogenic tick-borne relapsing fever spirochete}

Borrelia miyamotoi is a recently described relapsing fever spirochete transmitted by ticks of the Ixodes ricinus complex. This pathogen is different from Borrelia burgdorferi sensu lato (the Lyme borreliosis spirochetes) in its epidemiology, ecology and also genetics. Over 50 patients have been described worldwide with Borrelia miyamotoi disease, and three immunocompromised patients were reported with neurological symptoms. Our knowledge about Borrelia miyamotoi infection in ticks and its distribution in different habitats and also the mechanism of the infection is limited. The most common symptom is fever; thus it can be easily confused with other tick-borne diseases. Due to the intensive research in recent years, Borrelia miyamotoi infection in ticks and hosts has been reported from different regions and also the number of patients is increasing, thus this bacterium is considered as an emerging pathogen. In this literature review we would like to summarize the available knowledge about this spirochete.

Keywords: Borrelia miyamotoi, tick, relapsing fever, tick-borne infections

Szekeres S, Lakos A, Földvári G. [Borrelia miyamotoi: a recently identified human pathogenic tick-borne relapsing fever spirochete]. Orv Hetil. 2017, 158(29): 1124-1130.

(Beérkezett: 2017. április 20.; elfogadva: 2017. május 25.) 


\section{Szószedet}

Gazda: Olyan élőlény, amelyen (vagy amelyben) egy másik élőlény (parazita) él és táplálkozik.

Hordozó: Olyan gerinces állat, amelyben a kórokozó jelen van, hordozza a fertózést, de nem tudja továbbadni egy vektornak. Rezervoár: Olyan állatfaj, amely nemcsak hordozni, hanem fenntartani és továbbadni is képes a fertőzést a rajta szívó kullancsnak. Szervezetében a kórokozó tüneteket nem okoz, de szaporodik, így a rezervoár gazda jelenléte növeli a kórokozó előfordulási gyakoriságát az adott területen. A rezervoár gazdákat xenodiagnosztikával lehet azonosítani.

Transzovariális (vertikális) fertôződés: Olyan fertőződési mód, amelynek során a fertőzött, megtermékenyített nőstény kullancs petefészkén keresztül adja át a kórokozót az utódjának, így már a lárva is fertőzóképes lehet.

Xenodiagnózis: Olyan kísérleti forma, amelyben egy fertőzést hordozó gerinces fajról laboratóriumi kísérletek során bizonyítják be, hogy képes egy fertôzést továbbadni a rajta vért szívó kullancsnak.

Vektor: Olyan élőlény, amely képes a kórokozót egyik gazdaszervezetről a másikra továbbítani.

A kullancsok (Acari: Ixodidae) és az általuk terjesztett kórokozók az utóbbi évtizedekben a figyelem középpontjába kerültek. A közönséges kullancs (Ixodes ricinus) az északi féltekén, a mérsékelt égövi zónában általánosan elterjedt kullancsfaj, amely széles gazdaspektrummal rendelkezik. Több mint 300, szárazföldi gerinces állatfajról tudjuk, hogy e kullancsfaj táplálékforrásaként szolgálnak [1]. A fejlődő kullancsok legfőbb táplálékforrásai a kisemlősök, gyíkok és madarak. Az I. ricinus egy háromgazdás kullancsfaj, ez azt jelenti, hogy a fejlődése során ahhoz, hogy vedléssel az egyik stádiumból a következőbe fejlődjön, szüksége van három különböző gazdaszervezetre. Az I. ricinus által terjesztett legismertebb kórokozók a Lyme-kórt okozó Borrelia burgdorferi s.l. (sensu lato) fajcsoportba tartozó spirochaeta baktériumok. Ezenkívül más baktériumokat, például Anaplasma phagocytophilum, Candidatus Neoehrlichia mikurensis, Rickettsia spp., Francisella tularensis és vírusokat (a mi régiónkban a kullancsencephalitis-vírust) is terjeszthet a közönséges kullancs, amelyek többé-kevésbé jellegzetes kórképeket okoznak $[2,3]$.

\section{A kórokozó}

A kullancsok által terjesztett egyik legújabban felfedezett kórokozó az 1995-ben Fukunaga és mtsai által, Hokkaidó szigetéról származó Ixodes persulcatus kullancsból és Apodemus argenteus rágcsálóból izolált Borrelia miyamotoi [4]. A kórokozó Kenji Miyamoto japán entomológusról kapta nevét, aki elsőként izolált spirochaetákat kullancsokból a szigetországban. Az északi féltekén, a mérsékelt égövben elterjedt Ixodes ricinus fajcsoport kullancsai a legfóbb vektorai a B. miyamotoi-nak. A Borrelia nem (genus) két nagy, jól elkülöníthető csoportra osztható; a Lyme-kórt okozó Borrelia burgdorferi s.l. fajcso- portra és a visszatérő lázat okozó kórokozókra (relapsing fever spirochetes). A B. miyamotoi az utóbb említett, legfóképpen óvantagok (Argasidae) és tetvek (Phthiraptera) által terjedő baktériumok csoportjába tartozik.

A három, kullancsok által terjesztett, visszatérő lázat okozó spirochaeta (B. miyamotoi, a $B$. theileri és a $B$. lonestari) genetikailag jól elkülönül a többi (nem kullancsok által terjesztett) visszatérő láz kórokozótól (mint például a ruhatetúvel terjedő Borrelia recurrentis). A $B$. miyamotoi, ellentétben a B. burgdorferi-vel, amely rövid ideig van jelen a vérkeringésben és a transzovariális átvitele nem bizonyított, a vérben nagy számban jelen van [5], és a kullancsban anyáról utódra való átvitele is igen gyakori [6]. Korábban azt tartották, hogy emberre nem veszélyes, apatogén baktérium. A közelmúltban intenzív vizsgálatok folytak világszerte, amelyek alapján nemcsak egyre több helyrôl publikáltak adatokat arról, hogy a kórokozót kullancsokból és gazdáikból is kimutatták, hanem folyamatosan növekszik a dokumentált humán esetszám is, ezért növekvő jelentőségű, újonnan felbukkanó (emerging) kórokozóként tartják számon.

\section{A Borrelia miyamotoi elófordulása vektorokban}

A genetikai vizsgálatok alapján a $B$. miyamoto $i$ három jól elkülönülő típusba sorolható: egy amerikai, egy európai és egy ázsiai típusba [7]. E három B. miyamotoi típusnak különböző, jellemző kullancsvektora van. Az európait az I. ricinus, az ázsiait a $I$. persulcatus, az amerikait pedig az I. pacificus vagy az I. scapularis [2] kullancsfaj terjeszti.

Az előbbieken túl még más, Ixodes nembe tartozó kullancsból is kimutatták (I. dentatus, I. ovatus és az I. pavlovsky) $[2,3]$. Az első európai molekuláris adatok svéd és német közönséges kullancsokból származnak [8,9]. Ezek a cikkek még mint „B. miyamotoi-szerü” és „visszatérő láz kórokozószerü" baktériumot említik. Több esetben is előfordult, hogy más borreliákkal együtt találták meg társfertőzésként. Az emberek kullancscsípés alkalmával fertőződnek a korábban fertőzött kisemlősön táplálkozó (nimfa vagy adult) vagy a már fertőzötten kikelő (lárva) kullancsoktól. A fertőzött nőstény kullancsok utódainak akár 73\%-ába is átkerülhet a mikroba [6]. A fertőzött kullancslárvák képesek vért szívni emberekből is. Kísérletes adatok alapján a fertőzött lárvák pedig képesek táplálkozásuk során a fertőzést emlős gazdáiknak továbbadni [10].

Vadon élő rágcsálókban, amelyek újra és újra fertőződnek kullancslárvákkal, B. miyamotoi bacteraemia volt megfigyelhető, így fontos szerepük lehet ennek a kórokozónak a fenntartásában is [11, 12].

A kórokozó viszonylag alacsony prevalenciával egész Európában megtalálható a közönséges kullancs lárváiban, nimfáiban és a kifejlett egyedeiben is. Észt kutatások I. persulcatus-ban európai és ázsiai B. miyamotoi típust egyaránt találtak. 
A B. miyamotoi nagy területen elterjedt, jelenleg 18 európai országból van adat az előfordulásáról (1. táblázat) $[8,9,13-29]$. A növényzetről gyüjtött közönséges kullancsokban a fertőzöttek aránya $0,18 \%$ és $4,8 \%$ közötti. Magyarországon először Gemencen, egy erdei élőhelyen gyưjtött I. ricinus nimfákból mutatták ki a kórokozót [13].

\section{A kórokozó rágcsálókban és egyéb gerincesekben}

A B. miyamotoi életciklusában az egerek és pockok nagyon fontos szerepet játszanak. Eddig nyolc kisrágcsáló és négy egyéb gerinces fajban (vaddisznó, őz, vadpulyka és fekete rigó) vagy azok kullancsaiban mutattak ki $B$. miyamotoi-fertózést (2. táblázat) [2, 4, 11-14, 30-32]. Európában elsőként a vöröshátú erdeipocokból mutatták ki francia kutatók [30]. Azóta hazánkban és Szlovákiában is megtalálták sárganyakú erdeiegérben és vöröshátú erdeipocokban $[13,14]$. A hazai vizsgálatok mutattak rá először, hogy ezt a kórokozót a vadon élő sárganyakú erdeiegerek hordozhatják [13]. E két rágcsálóról xenodiagnosztikai vizsgálatok során kiderült, hogy nemcsak fenntartják a fertőzést, hanem a kórokozók szaporodni is képesek bennük [33], így egy élőhelyen akár fel is tudják erősíteni az ott jelen lévő fertőzést. Észak-Amerikában a fehér lábú egérról (Peromyscus leucopus) bizonyították, hogy a két európai rágcsálóhoz hasonlóan rezervoárja a spirochaetáknak [5]. Ezenfelül Tennessee államból származó pulykákban (Meleagris gallopavo) is magas prevalenciával (58\%) találták meg a kórokozót [31] (2. táblázat).

A rágcsálókon kívül más gazdafajok is a potenciális rezervoárok közé sorolhatók, például a $B$. miyamotoi-t megtalálták lengyelországi vaddisznókról (Sus scrofa), őzekről (Capreolus capreolus) és fekete rigókról (Turdus merula) gyújtött kullancsokban [32].

\section{Klinikum és epidemiológia}

Az elterjedéséról még nincsen elegendő adatunk, de úgy tünik, hogy ellentétben az egyéb, visszatérő lázat okozó borreliákkal, amelyek a mi régiónkban már nem fordulnak elő, ez az új mikroba a Lyme-kór elterjedésével azonos területen honos. Következik ez abból, hogy ugyanaz a vektora, mint a Lyme-kórnak, vagyis Európában az $I$. ricinus kullancsfaj. Ezért magyarországi előfordulásával is számolni kell. Egyelőre sokkal több országban találtak a kullancsokban B. miyamoto $i$-t, mint amennyiben humán megbetegedést észleltek (1. és 3. táblázat [34-40]). Ez érthető, hiszen mind a klinikai, mind a laboratóriumi diagnózis nehézkes. A klinikai tünetek között (3. táblázat) vezető a magas, gyakran $40{ }^{\circ} \mathrm{C}$ feletti láz, ami a kezeletlen esetekben is megszünik egy hét alatt, de azután visszatérhet. Amíg a többi visszatérő lázban néha tíz relapsus is előfordul, a B. miyamotoi-fertőzésben háromnál
1. táblázat |Borrelia miyamotoi előfordulása Európa különböző országaiból származó, terepen gyüjtött kullancsokban. Ahol elérhetőek voltak, ott feltüntettük a mintaszámokat

\begin{tabular}{|c|c|c|c|}
\hline Kullancsfaj & Ország & $\begin{array}{l}\text { Borrelia miyamotoi } \\
\text { (pozitív/vizsgált/ } \\
\text { prevalencia \%) }\end{array}$ & Referencia \\
\hline \multirow{24}{*}{$\begin{array}{l}\text { Ixodes } \\
\text { ricinus }\end{array}$} & Belgium & $5 / 439 / 1,1 \%$ & {$[15]$} \\
\hline & \multirow[t]{2}{*}{ Csehország } & $9 / 435 / 2 \%$ & [16] \\
\hline & & $2 / 1244 / 0,16 \% *$ & {$[17]$} \\
\hline & Dánia & $0,73 \% \#$ & [18] \\
\hline & Egyesült Királyság & $3 / 954 / 0,3 \%$ & [19] \\
\hline & Észtország & $\begin{array}{l}8 / 2622 / 0,4 \% \\
\text { (Bm európai típus) }\end{array}$ & {$[20]$} \\
\hline & Finnország & 2/777/0,3\% & {$[21]$} \\
\hline & \multirow[t]{3}{*}{ Franciaország } & $25 / 58 / 2,2 \%^{\#}$ & {$[22]$} \\
\hline & & $8 / 267 / 3 \%$ & {$[23]$} \\
\hline & & $1,72 \%{ }^{\#}$ & [18] \\
\hline & \multirow[t]{2}{*}{ Hollandia } & $20 / 520 / 3,8 \%$ & {$[15]$} \\
\hline & & $2,75 \%^{\#}$ & {$[18]$} \\
\hline & Írország & $8 / 756 / 1,1 \%$ ** & {$[24]$} \\
\hline & Lengyelország & $2 \%$ & {$[25]$} \\
\hline & Magyarország & $1 / 21 / 4,8 \%$ & {$[13]$} \\
\hline & \multirow[t]{2}{*}{ Németország } & $21 / 565 / 3,65 \%$ ** & [9] \\
\hline & & $4 / 226 / 1,8 \%$ & [16] \\
\hline & Norvégia & $11 / 1579 / 0,7 \%$ & {$[26]$} \\
\hline & Portugália & $1 / 640 / 0,16 \%$ & {$[27]$} \\
\hline & Románia & $7 / 468 / \mathbf{1}, \mathbf{5 \%}$ & [28] \\
\hline & \multirow[t]{3}{*}{ Svédország } & $2 / 301 / 0,7 \% *$ & [8] \\
\hline & & $1 / 399 / 0,3 \%$ & [29] \\
\hline & & $9 / 1331 / 0,7 \%$ & [21] \\
\hline & Szlovákia & $29 / 1696 / 1,7 \%$ & {$[14]$} \\
\hline $\begin{array}{l}\text { Ixodes } \\
\text { persulcatus }\end{array}$ & Észtország & $\begin{array}{l}15 / 561 / 2,7 \% \\
\text { (Bm ázsiai és európai } \\
\text { típus) }\end{array}$ & {$[20]$} \\
\hline
\end{tabular}

A táblázatban szereplő adatokat különféle módszerekkel nyerték, amelyeknek az érzékenysége is különböző.

*Bm-szerúként említve; **Rf-szerúként említve; "becsült prevalenciaérték a forrás szerint, egy mintát 25 egyed összevonásából képezték.

$\mathrm{Bm}=$ Borrelia miyamotoi Rf = visszatérő lázat okozó baktérium (Relapsing fever)

több relapsust még nem észleltek. Más kérdés, hogy nemigen fordul elő, hogy valaki egy hétig tartó láz miatt ne kapna antibiotikumot. Ha a láz vissza is tér, akkor már végképp kizárt, hogy ne kerülne sor antibiotikum-kezelésre. A lázhoz általános tünetek, borzongás, fejfájás, hányinger, ízületi és izomfájdalmak is társulnak. Nincsenek a fertőzésre utaló jellegzetes tünetek, amelyek segítenék a klinikust a diagnózis megállapításában. Az eddig észlelt 58 betegből három limfoproliferatív kórképben 


\begin{tabular}{|c|c|c|c|c|c|}
\hline Rágcsálófaj & Szövettípus & $\begin{array}{l}\text { PCR-prevalencia } \\
\text { (pozitív/vizsgált/prevalencia \%) }\end{array}$ & Ország & Járványtani szerep & Referencia \\
\hline \multirow{2}{*}{$\begin{array}{l}\text { Észak-amerikai fehérlábú egér } \\
\text { (Peromyscus leucopus) }\end{array}$} & Vér & $36 / 556 / 6,5 \%$ & \multirow{2}{*}{ USA } & \multirow{2}{*}{ Rezervoár } & \multirow[t]{2}{*}[12]{} \\
\hline & Bör & $2 / 86 / 2,32 \%$ & & & \\
\hline \multirow{3}{*}{$\begin{array}{l}\text { Európai sárganyakú erdeiegér } \\
\text { (Apodemus flavicollis) }\end{array}$} & Bőr & $1 / 102 / 0,9 \%$ & \multirow{2}{*}{ Magyarország } & \multirow{3}{*}{ Rezervoár } & [13] \\
\hline & Lép & $1 / 67 / 1,5 \%$ & & & \\
\hline & Bőr és lép & $33 / 356 / 9,3 \%$ & Szlovákia & & {$[14]$} \\
\hline \multirow{2}{*}{$\begin{array}{l}\text { Vöröshátú erdeipocok } \\
\text { (Myodes glareolus) }\end{array}$} & Lép & $4 / 72 / \mathbf{5 , 5 5} \%$ & Franciaország & \multirow{2}{*}{ Rezervoár } & {$[30]$} \\
\hline & Bőr és lép & $10 / 226 / 4,4 \%$ & Szlovákia & & {$[14]$} \\
\hline \multirow{2}{*}{$\begin{array}{l}\text { Kis japán erdeiegér } \\
\text { (A. argenteus) }\end{array}$} & Vér & - & \multirow{2}{*}{ Japán } & \multirow{2}{*}{ Hordozó } & {$[4]$} \\
\hline & Húgyhólyag & $1 / 137 / 0,7 \%$ & & & {$[11]$} \\
\hline \multirow{2}{*}{$\begin{array}{l}\text { Nagy japán erdeiegér } \\
\text { (A. speciosus) }\end{array}$} & Húgyhólyag & $10 / 446 / 2,2 \%$ & \multirow{2}{*}{ Japán } & \multirow{2}{*}{ Hordozó } & \multirow[t]{2}{*}[11]{} \\
\hline & Vér & $24 / 291 / 8,2 \%$ & & & \\
\hline Sarki erdeipocok (M. rutilus) & Vér & $3 / 56 / 5,4 \%$ & Japán & Hordozó & {$[11]$} \\
\hline \multirow{2}{*}{$\begin{array}{l}\text { Eurázsiai deres erdeipocok } \\
\text { (M.rufocanus) }\end{array}$} & Húgyhólyag & $2 / 195 / 2 \%$ & \multirow{2}{*}{ Japán } & \multirow{2}{*}{ Hordozó } & \multirow[t]{2}{*}[11]{} \\
\hline & Vér & $10 / 106 / 9,4 \%$ & & & \\
\hline Vaddisznó (Sus scrofa) & Kullancs* & 2 egyed & Lengyelország & Lehetséges hordozó & {$[32]$} \\
\hline $\begin{array}{l}\text { Eurázsai őz } \\
\text { (Capreolus capreolus) }\end{array}$ & Kullancs* & 2 egyed & Lengyelország & Lehetséges hordozó & {$[32]$} \\
\hline $\begin{array}{l}\text { Fekete rigó } \\
\text { (Turdus merula) }\end{array}$ & Kullancs* & 1 egyed & Lengyelország & Lehetséges hordozó & {$[32]$} \\
\hline $\begin{array}{l}\text { Vadpulyka } \\
\text { (Meleagris gallopavo) }\end{array}$ & $\begin{array}{l}\text { Vér és egyéb } \\
\text { szövet }\end{array}$ & $35 / 60 / 58 \%$ & USA & Hordozó & {$[31]$} \\
\hline
\end{tabular}

A táblázatban szereplő adatokat különféle módszerekkel nyerték, amelyeknek az érzékenysége is különböző.

*Kullancs táplálékának analízise: PCR-RFLP.

szenvedő, immunszupprimált emberben alakult ki meggyőzően alátámasztott, B. miyamotoi által okozott meningoencephalitis $[34,35]$. Mindegyik esetben lymphocytás pleocytosis és magas fehérjeszint volt a likvorban, ugyanúgy, mint a Lyme-betegségben. Néhány betegben alacsony fehérvérsejt- és vérlemezkeszámot, emelkedett májenzimértékeket mértek, vagyis a humán anaplasmosisra jellemző leleteket találtak. Több betegnek volt a Lyme-betegségre jellemzô erythema migransa (3. táblázat), ami bizonyos, hogy kombinált fertózés következménye.

A hagyományos Lyme-szerológiai eljárások, amelyek teljes Borrelia-sejtet használnak antigénként, a keresztreakciók miatt esetleg kimutatják a $B$. miyamotoi-fertőzést is. Létezik specifikusnak tartott szerológia, ami a $B$. miyamotoi egyik fehérjéjének (GlpQ) rekombináns változatát használja antigénként. Általános probléma azonban azokkal a bakteriális szerológiákkal, ahol nincs jellegzetes klinikai tünet, hogy nincs olyan klinikailag definiált betegminta, amelyen a szerológia megbízhatóságát (érzé- kenységét és specificitását) tesztelni lehetne. Csaknem lehetetlen feladat biztosan negatív és biztosan pozitív eseteket találni. Egy holland vizsgálat szerint 150 véradó 2\%-a volt szeropozitív [41]. Ez egyben azt jelenti, hogy a vizsgálat specificitása 98\%, ami nagyszerúnek túnik. Azonban még a sokkal gyakoribb Lyme-betegségben is, egy ilyen specificitású teszt esetén a szerológia pozitív prediktív értéke csupán 5\% [42]. Ez azt jelenti, hogy egy ilyen kiváló teszttel a pozitív Lyme-leletek 95\%-a téves! Egy ritkább betegségben ez az arány még sokkal alacsonyabb, vagyis egy pozitív $B$. miyamotoi-szerológiai eredmény nem jelent majd semmit, de félrevezeti a klinikusokat. Tehát, amennyiben ez a teszt elterjed, még több bajt fog okozni, mint a jelenlegi Lyme-diagnosztika.

Van azonban kiút, és ez a direkt sötét látóteres vizsgálat. Mivel a B. miyamotoi - ellentétben a Lyme spirochaetával - tömegesen van jelen a vérben, sötét látóteres kondenzorral felszerelt vagy fáziskontraszt-mikroszkóppal néhány látóteret átvizsgálva nagy eséllyel detektálható. Ehhez azonban friss, alvadásgátolt vérmintára és tapasz- 
3. táblázat | Emberi Borrelia miyamotoi megbetegedések és gyógykezelésük

\begin{tabular}{|c|c|c|c|c|c|c|}
\hline Ország & Páciens & Tünetek & Detektálás & $\begin{array}{l}\text { Kiegészítő } \\
\text { laborvizsgálatok }\end{array}$ & Terápia & Referencia \\
\hline \multirow{4}{*}{$\begin{array}{l}\text { Amerikai } \\
\text { Égyesült } \\
\text { Államok }\end{array}$} & $\begin{array}{l}\text { 5, tüneteket mutató } \\
\text { páciens, } \\
\text { szerokonverzióval }\end{array}$ & $\begin{array}{l}\text { Láz ( } 5 \text { esetben), erythema } \\
\text { migrans ( } 4 \text { esetben), } \\
\text { fejfájás, fáradtság, } \\
\text { nyakmerevség, ízületi } \\
\text { fájdalom, hasi fájdalom, } \\
\text { köhögés, torokgyulladás, } \\
\text { ágyéki nyirokcsomó- } \\
\text { gyulladás ( } 1 \text { esetben) }\end{array}$ & $\begin{array}{l}\text { GlpQ Elisa, GlpQ } \\
\text { Western blot }\end{array}$ & - & $\begin{array}{l}\text { Doxycyclin } 7-14 \\
\text { nap ( } 4 \text { esetben), } \\
\text { Amoxicilin/ } \\
\text { klavulánsav } \\
\text { ( } 1 \text { esetben) }\end{array}$ & {$[37]$} \\
\hline & 61 éves férfi & $\begin{array}{l}\text { Láz, hidegrázás, fejfájás, } \\
\text { fokozott fényérzékenység, } \\
\text { izom- és ízületi fájdalom, } \\
\text { anorexia }\end{array}$ & PCR & $\begin{array}{l}\text { Thropbocytopenia, } \\
\text { leukopenia, } \\
\text { emelkedett AST/ } \\
\text { ALT és CPK }\end{array}$ & $\begin{array}{l}\text { Doxycyclin } \\
2 \times 100 \mathrm{mg} \text { iv. } 4 \\
\text { nap, } 2 \times 100 \mathrm{mg} \\
\text { p. o. } 2 \text { hét }\end{array}$ & {$[38]$} \\
\hline & 87 éves férfi & $\begin{array}{l}\text { Láz, hidegrázás, légszomj, } \\
\text { anorexia, izommerevség }\end{array}$ & PCR & $\begin{array}{l}\text { Thropbocytopenia, } \\
\text { leukopenia, } \\
\text { emelkedett AST/ } \\
\text { ALT }\end{array}$ & $\begin{array}{l}\text { Doxycyclin } \\
2 \times 100 \mathrm{mg} \text { iv. } 2 \\
\text { nap, } 2 \times 100 \mathrm{mg} \\
\text { p. o. } 2 \text { hét }\end{array}$ & {$[38]$} \\
\hline & $\begin{array}{l}81 \text { éves } \\
\text { immunhiányos nő }\end{array}$ & $\begin{array}{l}\text { Mentális leépülés, } \\
\text { zavartság, szociális } \\
\text { visszahúzódás, fogyás, } \\
\text { mozgáskoordinációs zavar } \\
\text { és hallásromlás }\end{array}$ & $\begin{array}{l}\text { PCR }(\mathrm{CSF}) \text {, sötét } \\
\text { látóteres vizsgálat } \\
(\mathrm{CSF})\end{array}$ & $\begin{array}{l}\text { CSF: emelkedett } \\
\text { fehérje, sejtszám }\end{array}$ & $\begin{array}{l}\text { Ceftriaxon } 2 \mathrm{~g} \text { iv. } \\
\text { váltás penicillinre } \\
\text { iv. } 1 \text { hónap }\end{array}$ & [34] \\
\hline Oroszország & $\begin{array}{l}46 \text { páciens } \\
\text { „kullancsbetegség” } \\
\text { gyanújával }\end{array}$ & $\begin{array}{l}\text { Láz, fejfájás, izom- és } \\
\text { ízületi fájdalom, hidegrázás, } \\
\text { émelygés, erythema } \\
\text { migrans, hányás, } \\
\text { nyakmerevség }\end{array}$ & PCR & $\begin{array}{l}\text { Proteinuria, } \\
\text { emelkedett AST/ } \\
\text { ALT }\end{array}$ & $\begin{array}{l}\text { Ceftriaxon } 2 \mathrm{~g} \text { iv. } \\
2 \text { hét }(43 \text { esetben }), \\
\text { doxycyclin } 2 \times 100 \\
\text { mg p. o. } 2 \text { hét } \\
\text { ( } 3 \text { esetben) }\end{array}$ & {$[39]$} \\
\hline \multirow[b]{2}{*}{ Japán } & 72 éves nő & $\begin{array}{l}\text { Láz, erythema migrans, } \\
\text { anorexia, izomfájdalom }\end{array}$ & $\begin{array}{l}\text { PCR, GlpQ } \\
\text { Western blot }\end{array}$ & $\begin{array}{l}\text { Emelkedett AST/ } \\
\text { ALT és CPK, } \\
\text { leukopenia }\end{array}$ & $\begin{array}{l}\text { Minocyclin } 100 \\
\text { mg } 5 \text { nap }\end{array}$ & {$[40]$} \\
\hline & 37 éves férfi & Láz, erythema migrans & PCR & - & $\begin{array}{l}\text { Ceftiraxon } 1 \mathrm{~g} \text { iv. } \\
7 \text { nap folytatás } \\
\text { ismeretlen } \\
\text { antibiotikummal }\end{array}$ & {$[40]$} \\
\hline Hollandia & $\begin{array}{l}70 \text { éves } \\
\text { immunhiányos férfi }\end{array}$ & $\begin{array}{l}\text { Meglassult gondolkodás, } \\
\text { memóriazavar, } \\
\text { mozgáskoordinációs zavar }\end{array}$ & $\begin{array}{l}\text { PCR (vér és CSF), } \\
\text { sötét látóteres } \\
\text { vizsgálat }(\mathrm{CSF})\end{array}$ & $\begin{array}{l}\text { CSF: emelkedett } \\
\text { fehérje, sejtszám }\end{array}$ & $\begin{array}{l}\text { Ceftriaxon } 2 \mathrm{~g} \text { iv. } \\
2 \text { hét }\end{array}$ & {$[35]$} \\
\hline Németország & $\begin{array}{l}74 \text { éves } \\
\text { immunhiányos nő }\end{array}$ & $\begin{array}{l}\text { Szédülés, hányás, fejfájás, } \\
\text { nyakmerevség }\end{array}$ & $\begin{array}{l}\text { PCR (szérum és } \\
\text { CSF) }\end{array}$ & $\begin{array}{l}\text { CSF: emelkedett } \\
\text { fehérje, sejtszám }\end{array}$ & $\begin{array}{l}\text { Ceftriaxon } 2 \mathrm{~g} \text { iv. } \\
3 \text { hét }\end{array}$ & {$[36]$} \\
\hline
\end{tabular}

ALT = alanin-transzamináz; AST = aszpartát-transzamináz; CRP = C-reaktív protein; CSF = likvor-cerebrospinalis folyadék; iv. = intravénás; p. o.: per oralis

talt szakemberre lenne szükség. Sötét látóteres mikroszkóp sem lehet túl sok az országban. Maga a vizsgálat nem alkalmas tömeges alkalmazásra, tehát csak kivételesen jó klinikus-laboros kooperáció esetén számíthatunk sikerre. Van még elméleti lehetőség a PCR-re, ami egy ilyen, meglehetősen ritkának tûnő betegség esetén nem látszik költséghatékony diagnosztikai eljárásnak. A viszszatérô lázat okozó borreliák ugyanazokra az antibiotikumokra érzékenyek, mint a Lyme-baktériumok: második generációs penicillinszármazékok, ceftriaxon, doxycyclin az eddigi adatok szerint hatékonyak. Valószínúleg hatástalanok a szulfonamidok, kinolonok és az első generációs cefalosporinok.

\section{Összefoglalás és megválaszolandó kérdések}

A B. miyamotoi egy újonnan felfedezett, és növekvő jelentőségű, visszatérő lázat okozó, humán patogén baktérium, ami Európában, Ázsiában és Észak-Amerikában is megtalálható az Ixodes nembe tartozó kullancsokban. Eddig több mint 50 esetben okozott nem specifikus lázas megbetegedést és három esetben, immunhiányos betegekben súlyos neurológiai tüneteket is. A kórokozó természetes elterjedési területén gyakran fordulnak elő a lakosság szervezetében $B$. miyamotoi spirochaeta elleni antitestek. 
Mint a többi, kullancs által terjesztett kórokozó esetében is, az emberi fertőződés fő rizikófaktora a fertőzött kullanccsal való kontaktus, emiatt is fontos a kullancsok és rezervoár gazdák vizsgálata. A kórokozó kimutatására többféle molekuláris biológiai eljárást alkalmaznak a különböző laboratóriumokban $[35,36]$. Ezek érzékenysége és megbízhatósága eltérő, így a különböző területeken meghatározott prevalencia direkt összehasonlítása nem lehetséges.

A fertőzés azonosítása komplikált, mert a B. miyamotoi és a B. burgdorferi s.l. baktériumok azonos kullancsvektorban találhatóak meg, és a $B$. miyamotoi-fertőzés nem alakít ki specifikus tüneteket. Hasonló tünetek több, kullancs által terjesztett fertőzésre is jellemzőek lehetnek (például a Lyme borreliosisra, a humán granulocytás anaplasmosisra, a rikettsiosisra, valamint az óvantagok által terjesztett visszatérő lázra). Ezért, ha egy beteg lázas vagy idegrendszeri tüneteket mutat kullancscsípést követően az I. ricinus fajkomplex elterjedési területén, akkor a $B$. miyamotoi-fertőzés lehetőségét is figyelembe kell venni.

Számos a megválaszolatlan kérdés még a $B$. miyamoto $i$-val kapcsolatban. Nem tudjuk például, hogy az eltérő genetikai variánsok összefüggésben vannak-e eltérő patogenitással, vektoraffinitással vagy a rezervoár gazda típusával. Ismeretlen annak az oka is, hogy miért kullancsokban és nem óvantagokban fordul elő a B. miyamotoi, és tisztázásra vár a pontos járványtani ciklus is. Jelentős diagnosztikai kihívás a jövőre nézve, hogy a $B$. miyamotoi-fertőzést társfertőzésekben is azonosítani lehessen, illetve, hogy ezek klinikai következményeit is megismerjük.

A B. miyamotoi 2014 óta sikeresen tenyészthető módosított Kelly-Pettenkofer-médiumban [43]. Ez valószínúleg segíteni fog abban, hogy közelebbről megérthessük a kórokozó fertőzésdinamikáját, gazdában és vektorban való túlélésének, valamint az emberben kialakított kórképének a kulcsfaktorait.

Anyagi támogatás: F. G.-t a Magyar Tudományos Akadémia Bolyai János Kutatási Ösztöndíja, Sz. S.-t a Magyar Állami Eötvös Ösztöndíj és az EurNegVec Cost Action TD1303 támogatta.

Szerzői munkamegosztás: Sz. S., F. G. írta a Szószedetet, az általános bevezetést, „A kórokozó”, a „Borrelia miyamotoi előfordulása vektorokban”, „A kórokozó rágcsálókban és egyéb gerincesekben” és az „Összefoglalás és megválaszolandó kérdések” részeket. L. A. írta a „Klinikum és epidemiológia” részt. Sz. S. készítette a táblázatokat és az irodalomjegyzéket. A cikk végleges változatát mindhárom szerző elolvasta és jóváhagyta.

Érdekeltségek: A szerzőknek nincsenek érdekeltségeik.

\section{Irodalom}

[1] Földvári G. Life cycle and ecology of Ixodes ricinus: the roots of public health importance. In: Braks MA, van Wieren SE, Takken W, et al. (eds.) Ecology and prevention of Lyme borreliosis. (Ecology and control of vector-borne diseases, volume 4). Wageningen Academic Publishers, Wageningen, 2016; pp. 31-40.

[2] Wagemakers A, Staarink PJ, Sprong H, et al. Borrelia miyamotoi: a widespread tick-borne relapsing fever spirochete. Trends Parasitol. 2015; 31: 260-269.

[3] Siński E, Welc-Falęciak R, Zajkowska J. Borrelia miyamotoi: A human tick-borne relapsing fever spirochete in Europe and its potential impact on public health. Adv Med Sci. 2016; 61: 255260.

[4] Fukunaga M, Takahashi Y, Tsuruta Y, et al. Genetic and phenotypic analysis of Borrelia miyamotoi sp. nov., isolated from the ixodid tick Ixodes persulcatus, the vector for Lyme disease in Japan. Int J Syst Bacteriol. 1995; 45: 804-810.

[5] Bunikis J, Barbour AG. Third Borrelia species in white-footed mice. Emerg Infect Dis. 2005; 11: 1150-1151.

[6] Scoles GA, Papero M, Beati L, et al. A relapsing fever group spirochete transmitted by Ixodes scapularis ticks. Vector Borne Zoonotic Dis. 2001; 1: 21-34.

[7] Mukhacheva TA, Salikhova II, Kovalev SY. Multilocus spacer analysis revealed highly homogeneous genetic background of Asian type of Borrelia miyamotoi. Infect Genet Evol. 2015; 31 : 257-262.

[8] Fraenkel C, Garpmo U, Berglund J. Determination of novel Borrelia genospecies in Swedish Ixodes ricinus ticks. J Clin Microbiol. 2002; 40: 3308-3312.

[9] Richter D, Schlee DB, Matuschka FR. Relapsing fever-like spirochetes infecting European vector tick of Lyme disease agent. Emerg Infect Dis. 2003; 9: 697-701.

[10] van Duijvendijk G, Coipan C, Wagemakers A, et al. Larvae of Ixodes ricinus transmit Borrelia afzelii and B. miyamoto $i$ to vertebrate hosts. Parasit Vectors 2016; 9: 97.

[11] Taylor KR, Takano A, Konnai S, et al. Borrelia miyamotoi infections among wild rodents show age and month independence and correlation with Ixodes persulcatus larval attachment in Hokkaido, Japan. Vector Borne Zoonotic Dis. 2013; 13: 92-97.

[12] Barbour AG, Bunikis J, Travinsky B, et al. Niche partitioning of Borrelia burgdorferi and Borrelia miyamoto $i$ in the same tick vector and mammalian reservoir species. Am J Trop Med Hyg. 2009; 81: 1120-1131.

[13] Szekeres S, Coipan EC, Rigó K, et al. Eco-epidemiology of Borrelia miyamotoi and Lyme borreliosis spirochetes in a popular hunting and recreational forest area in Hungary. Parasit Vectors 2015; 8: 309

[14] Hamšíková Z, Coipan C, Mahríková L, et al. Borrelia miyamotoi and co-infection with Borrelia afzelii in Ixodes ricinus ticks and rodents from Slovakia. Microb Ecol. 2017; 73: 1000-1008.

[15] Cochez C, Heyman P, Heylen D, et al. The presence of Borrelia miyamotoi, a relapsing fever spirochaete, in questing Ixodes ricimus in Belgium and in The Netherlands. Zoonoses Public Health 2015; 62: 331-333

[16] Crowder CD, Carolan HE, Rounds MA, et al. Prevalence of Borrelia miyamotoi in Ixodes ticks in Europe and the United States. Emerg Infect Dis. 2014; 20: 1678-1682.

[17] Hulínská D, Votýpka J, Kř́ž B, et al. Phenotypic and genotypic analysis of Borrelia spp. isolated from Ixodes ricinus ticks by using electrophoretic chips and real-time polymerase chain reaction. Folia Microbiol (Praha) 2007; 52: 315-324.

[18] Michelet L, Delannoy S, Devillers E, et al. High-throughput screening of tick-borne pathogens in Europe. Front Cell Infect Microbiol. 2014; 4: 103. 
[19] Hansford KM, Fonville M, Jahfari S, et al. Borrelia miyamoto $i$ in host-seeking Ixodes ricinus ticks in England. Epidemiol Infect. 2015; 143: 1079-1087.

[20] Geller J, Nazarova L, Katargina O, et al. Detection and genetic characterization of relapsing fever spirochete Borrelia miyamotoi in Estonian ticks. PLoS One 2012; 7: e51914.

[21] Wilhelmsson P, Lindblom P, Fryland L, et al. Prevalence, diversity, and load of Borrelia species in ticks that have fed on humans in regions of Sweden and Åland islands, Finland with different Lyme borreliosis incidences. PLoS One 2013; 8: e81433.

[22] Vayssier-Taussat M, Moutailler S, Michelet L, et al. Next generation sequencing uncovers unexpected bacterial pathogens in ticks in western Europe. PLoS One 2013; 8: e81439.

[23] Cosson JF, Michelet L, Chotte J, et al. Genetic characterization of the human relapsing fever spirochete Borrelia miyamotoi in vectors and animal reservoirs of Lyme disease spirochetes in France. Parasit Vectors 2014; 7: 233.

[24] Pichon B, Rogers M, Egan D, et al. Blood-meal analysis for the identification of reservoir hosts of tick-borne pathogens in Ireland. Vector Borne Zoonotic Dis. 2005; 5: 172-180.

[25] Kiewra D, Stańczak J, Richter M. Ixodes ricinus ticks (Acari, Ixodidae) as a vector of Borrelia burgdorferi sensu lato and Borrelia miyamoto $i$ in Lower Silesia, Poland-preliminary study. Ticks Tick Borne Dis. 2014; 5: 892-897.

[26] Kjelland V, Rollum R, Korslund L, et al. Borrelia miyamotoi is widespread in Ixodes ricinus ticks in southern Norway. Ticks Tick Borne Dis. 2015; 6: 516-521.

[27] Nunes M, Parreira R, Lopes N, et al. Molecular identification of Borrelia miyamotoi in Ixodes ricinus from Portugal. Vector Borne Zoonotic Dis. 2015; 15: 515-517.

[28] Kalmár Z, Sprong H, Mihalca AD, et al. Borrelia miyamotoi and Candidatus Neoehrlichia mikurensis in Ixodes ricinus Ticks, Romania. Emerg Infect Dis. 2016; 22: 550-551.

[29] Wilhelmsson P, Fryland L, Börjesson S, et al. Prevalence and diversity of Borrelia species in ticks that have bitten humans in Sweden. J Clin Microbiol. 2010; 48: 4169-4176.

[30] Cosson JF, Michelet L, Chotte J, et al. Genetic characterization of the human relapsing fever spirochete Borrelia miyamotoi in vectors and animal reservoirs of Lyme disease spirochetes in France. Parasit Vectors 2014; 7: 233.

[31] Scott MC, Rosen ME, Hamer SA, et al. High-prevalence Borrelia miyamotoi infection among wild turkeys (Meleagris gallopavo) in Tennessee. J Med Entomol. 2010; 47: 1238-1242.

[32] Wodecka B, Rymaszewska A, Skotarczak B. Host and pathogen DNA identification in blood meals of nymphal Ixodes ricinus ticks from forest parks and rural forests of Poland. Exp Appl Acarol. 2014; 62: 543-555.

[33] Burri C, Schumann O, Schumann C, et al. Are Apodemus spp. mice and Myodes glareolus reservoirs for Borrelia miyamotoi, Candidatus Neoehrlichia mikurensis, Rickettsia helvetica, $R$. monacensis and Anaplasma phagocytophilum? Ticks Tick Borne Dis. 2014; 5: 245-251.

[34] Gugliotta JL, Goethert HK, Berardi VP, et al. Meningoencephalitis from Borrelia miyamotoi in an immunocompromised patient. N Engl J Med. 2013; 368: 240-245.

[35] Hovius JWR, de Wever B, Sohne M, et al. A case of meningoencephalitis by the relapsing fever spirochaete Borrelia miyamoto $i$ in Europe. Lancet 2013; 382: 658.

[36] Boden K, Lobenstein S, Hermann B, et al. Borrelia miyamotoiassociated neuroborreliosis in immunocompromised person. Emerg Infect Dis. 2016; 22: 1617-1620.

[37] Krause PJ, Narasimhan S, Wormser GP, et al. Borrelia miyamotoi sensu lato seroreactivity and seroprevalence in the northeastern United States. Emerg Infect Dis. 2014; 20: 1183-1190.

[38] Chowdri HR, Gugliotta JL, Berardi VP, et al. Borrelia miyamotoi infection presenting as human granulocytic anaplasmosis: a case report. Ann Intern Med. 2013; 159: 21-27.

[39] Platonov AE, Karan LS, Kolyasnikova NM, et al. Humans infected with relapsing fever spirochete Borrelia miyamotoi, Russia. Emerg Infect Dis. 2011; 17: 1816-1823.

[40] Sato K, Takano A, Konnai S, et al. Human infections with Borrelia miyamotoi, Japan. Emerg Infect Dis. 2014; 20: 1391-1393.

[41] Jahfari S, Herremans T, Platonov AE, et al. High seroprevalence of Borrelia miyamotoi antibodies in forestry workers and individuals suspected of human granulocytic anaplasmosis in the Netherlands. New Microbes New Infect. 2014; 2: 144-149.

[42] Lakos A, Reiczigel J, Solymosi N. The positive predictive value of Borrelia burgdorferi serology in the light of symptoms of patients sent to an outpatient service for tick-borne diseases. Inflamm Res. 2010; 59: 959-964.

[43] Wagemakers A, Oei A, Fikrig MM, et al. The relapsing fever spirochete Borrelia miyamotoi is cultivable in a modified KellyPettenkofer medium, and is resistant to human complement. Parasit Vectors 2014; 7: 418.

(Földvári Gábor dr., Budapest, István u. 2., 1078 e-mail: FoldvariGabor@gmx.de)

\section{Tisztelt Szerzőink, Olvasóink!}

Az Orvosi Hetilapban megjelenő/megjelent közlemények elérhetőségére több lehetőség kínálkozik.

Rendelhető különlenyomat, melynek áráról bővebben a www.akkrt.hu honlapon (Folyóirat Szerzőknek, Különlenyomat menüpont alatt) vagy Szerkesztöségünkben tájékozódhatnak.

A közlemények megvásárolhatók pdf-formátumban is, illetve igényelhető Optional Open Article (www.oopenart.com).

Adott dij ellenében az online közlemények bárki számára hozzáférhetök honlapunkon (a közlemények külön linket kapnak, így más oldalról is linkelhetövé válnak).

Bővebb információ a hirdetes@akkrt.hu címen vagy különlenyomat rendelése esetén a Szerkesztőségtől kérhető. 